\title{
Determination of Cell Membrane Signal by using NMR Spectroscopy
}

\author{
Sibel Korunur ${ }^{1 *}$, Ali Yilmaz ${ }^{2}$ \\ I*Munzur University, Tunceli Vocational School, Electricity and Energy Department, 62000 Tunceli, Turkey, \\ skorunur@munzur.edu.tr $\underline{\text { D }}$ \\ ${ }^{2}$ Batman University, Faculty of Science, Department of Physics, Batman, ali.yilmaz@batman.edu.tr \\ Received date: 30.11.2017, Accepted date: 25.04.2018
}

\begin{abstract}
The cell membrane forms the boundaries of the cell and regulates the passage of matter between the inside and the outside of the cell. Cell membranes play a major role in the process of taking the necessary nutrients from the outside and exerting the harmful metabolites resulting from the metabolism. In this study, $400 \mathrm{MHz}{ }^{1} \mathrm{H}-\mathrm{NMR}$ spectrum of a membrane sample in an aqueous solution was taken using single pulse and presaturation method and it has been tried to determine the location of the membrane signal by comparing these two spectrums.
\end{abstract}

Keywords: Cell membrane, nuclear magnetic resonance, presaturation method

\section{Hücre Zarı Sinyalinin NMR Spektroskopisi ile Belirlenmesi}

\section{$\ddot{O} z$}

Hücre zarı, hücrenin sınırlarını oluşturur ve hücre içi ile dışı arasındaki madde geçişini düzenler. Hücrenin kendisi için gerekli besin maddelerini dış ortamdan alıp metabolizma sonucu oluşan zararlı metabolitleri dış ortama verme olayında hücre zarlarının büyük bir rolü bulunmaktadır. Bu çalışmada sulu çözeltideki bir hücre zarı örneğinin 400 $\mathrm{MHz}{ }^{1} \mathrm{H}-\mathrm{NMR}$ spektrumu, tek puls ve presaturasyon metodu kullanılarak alınmış ve bu iki spektrumun karşılaştırmasıyla hücre zarı sinyalinin yeri saptanmaya çalışılmıştır.

Anahtar kelimeler: Hücre zarı, nükleer manyetik rezonans, presaturasyon metodu

\section{INTRODUCTION}

The nuclear magnetic resonance (NMR) phenomenon has been known for decades and NMR spectroscopy has been used as a powerful tool in physicochemical analyzes for almost fifty years (Marion, 2013). With the progress of the technology, the free induction decay (FID) signals can be transformed into shapes by using programs similar to those used in the analogue scaling programs used in the scantography (Grover et al., 2015). At the basis of nuclear magnetic resonance studies lies the magnetic nature of the core (Webb, 2007). The electric current creates a magnetic field around it. An atomic nucleus that rotates around the axis forms a magnetic field around it, as it is charged due to the electrons in it. Technically, magnetic resonance studies the behavior of the nuclei of atoms with magnetization properties.

Biological membranes are dynamic systems containing lipids and proteins. Membranes act as selective permeable barrier and contain transport and displacement (translocation) systems that regulate the structure of the intracellular environment, as well as specific receptors for cell signaling studies (Schnell and Hebert, 2003).

Homology calculations of the human genome sequence reveal that $30 \%$ of the proteins are membrane-associated (Babcock and Li, 2014). Since a large of majority of best-selling drugs target membrane receptors, membrane-related proteins are of interest to the pharmaceutical and biotechnology industry (Bull and Doig, 2015).

Investigation of the interaction of drugs with biological membranes and membrane-associated proteins using NMR spectroscopy and other spectroscopic methods has been the focus of recent years (Opella et al., 2001; Xu et al., 2002; Nielsen et al., 2004; Middleton et al., 2004; Pignatello et al., 2011).

Liquid NMR has been recognized as an important method in the determination of structures of readily soluble protein and protein complexes in aqueous solutions. (Thennarasu et al., 2005; Tamm and Liang, 2006). It is also possible to obtain information about the molecular dynamics of the system by calculating $T_{1}$ and $T_{2}$ relaxation times in 
DOI: 10.29132/ijpas.359756

aqueous solutions with Liquid NMR. (Wüthrich, 1986; Yilmaz and Zengin, 2013; Yilmaz and et al., 2014).

When membrane proteins are embedded in lipid layers, using liquid NMR techniques is not appropriate. Because the rotation of these membrane proteins around their surroundings is slow and largely anisotropic. This leads to improper relaxation and very large resonance signals that cannot be detected. The solid state NMR is a successful method for finding high-resolution spectra of membranes attached to peptides and proteins in lipid layers (Abu-Baker and Lorigan, 2012).

In this study, a $400 \mathrm{MHz}{ }^{1} \mathrm{H}-\mathrm{NMR}$ spectrum of a normal (healthy) membrane sample in an aqueous solution was taken by two techniques (single puls and presaturation) and the position of membrane signal in this spectrum was tried to be determined by the comparison method of two spectrum.

\section{MATERIAL AND METHOD}

In this work, $\mathrm{D}_{2} \mathrm{O}$ used as solvent was obtained from Sigma-Aldrich catalog. Membrane samples were obtained from the Department of Biophysics, Faculty of Medicine, Ankara University. Normal (healthy) membrane samples were heart homogenates obtained from 4-month-old healthy rabbits. The normal membrane sample was reacted with $\mathrm{D}_{2} \mathrm{O}$ and $400 \mathrm{MHz}{ }^{1} \mathrm{H}-\mathrm{NMR}$ spectra of these samples were investigated.

In order to determine the membrane signal, 400 $\mathrm{MHz}{ }^{1} \mathrm{H}-\mathrm{NMR}$ spectrum of $\mathrm{D}_{2} \mathrm{O}$ and the buffer solution mixture in which the membrane samples were homogenized was taken using single pulse and presaturation (suppression) method. Then $400 \mathrm{MHz}$ ${ }^{1} \mathrm{H}-\mathrm{NMR}$ spectrum of the $\mathrm{D}_{2} \mathrm{O}$ and the membrane sample mixture was taken using single pulse and presaturation method. As a result of these two spectrum comparisons, we have an idea of the location of the membrane sample in the spectrum.

An NMR spectrum example with and without solvent presaturation method was shown in Figure 1 (Jao, 2005). In Figure 1(a), the solvent peak is very intense, so the intensity of the other peaks is rather small. In Figure 1(b), the solvent pike was suppressed by solvent presaturation method, so that the intensity of the other peaks was increased.

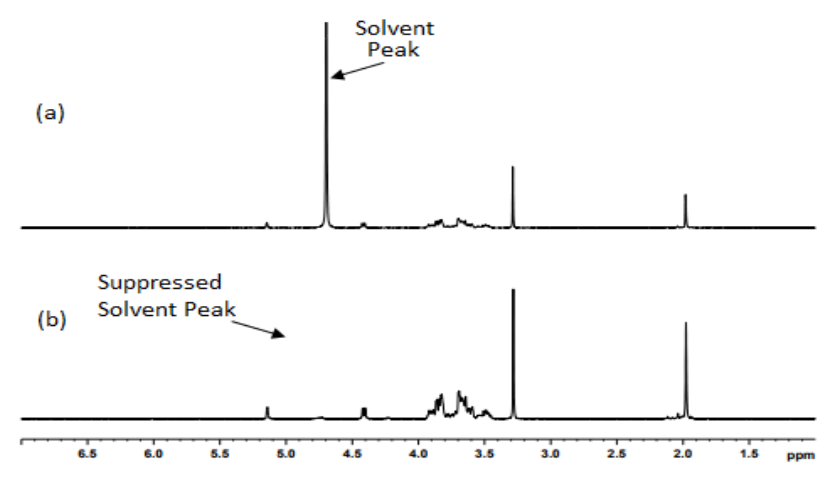

Figure 1. (a) Spectrum without solvent suppression method (b) Spectrum with solvent suppression method

When the $\mathrm{H}_{2} \mathrm{O}+\mathrm{D}_{2} \mathrm{O}$ mixture was used as the solvent, the water peak is quite large. In order to be able to see the other signs in the spectrum, the water peak has to be suppressed effectively. In this study, in order to effectively suppress the water peak and to see the other peaks better, the ZGPR pulse step was selected in the BRUKER NMR AVANCE 400 Running TOPSPIN program. In order to effectively suppress the water peak with the ZGPR pulse program, a single pulse experiment was performed first. Then, the $\mathrm{O} 1$ resonance frequency, which will suppress the water peak, was detected from the spectrum and this frequency value was written in the pulse program. The water peak suppression experiment was completed by selecting the other parameters in the pulse program appropriately.

\section{RESULTS AND DISCUSSION}

The $400 \mathrm{MHz}{ }^{1} \mathrm{H}-\mathrm{NMR}$ spectrum of the membrane sample with the buffer solution in which the membrane samples were homogenized. These spectrums were given in Figure 2. Figure 2a shows the ${ }^{1} \mathrm{H}-\mathrm{NMR}$ spectrum of a $900 \mu \mathrm{L} \mathrm{D}_{2} \mathrm{O}$ mixture with $100 \mu \mathrm{L}$ of the buffer solution and Figure $2 \mathrm{~b}$ gives the ${ }^{1} \mathrm{H}-\mathrm{NMR}$ spectrum of the $980 \mu \mathrm{L} \quad \mathrm{D}_{2} \mathrm{O}$ mixtures with the $20 \mu \mathrm{L}$ membrane sample on the same vertical scale. When these two spectra were compared, it was seen that the only difference was the signal observed at the chemical shift value of $0.0046 \mathrm{ppm}$ in the ${ }^{1} \mathrm{H}-\mathrm{NMR}$ spectrum of the $\mathrm{D}_{2} \mathrm{O}$ mixture with the membrane sample. As a result, this signal was taken into account in the membrane samples. 
DOI: 10.29132/ijpas.359756

(a)

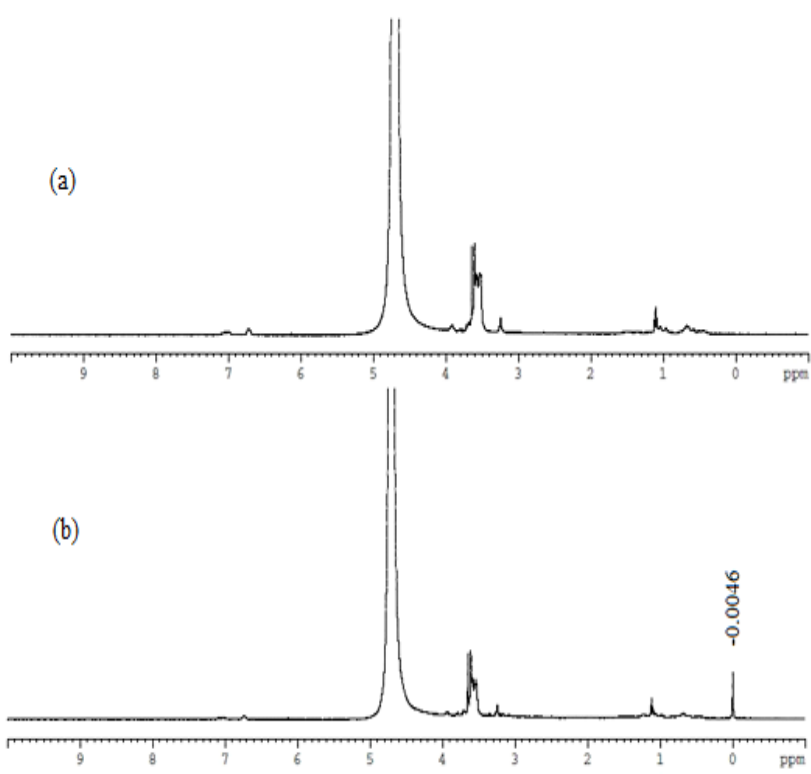

Figure 2. (a) NMR spectrum (with single puls techniques) of Buffer solution $+\mathrm{D}_{2} \mathrm{O}$ mixture (b) NMR spectrum (with single puls techniques) of membrane $+\mathrm{D}_{2} \mathrm{O}$ mixture

Figure 3 shows the result of suppression of the HDO signal using the presaturation method in the $400 \mathrm{MHz}{ }^{1} \mathrm{H}-\mathrm{NMR}$ spectrum of the membrane sample with the buffer solution in which the membrane samples were homogenized.
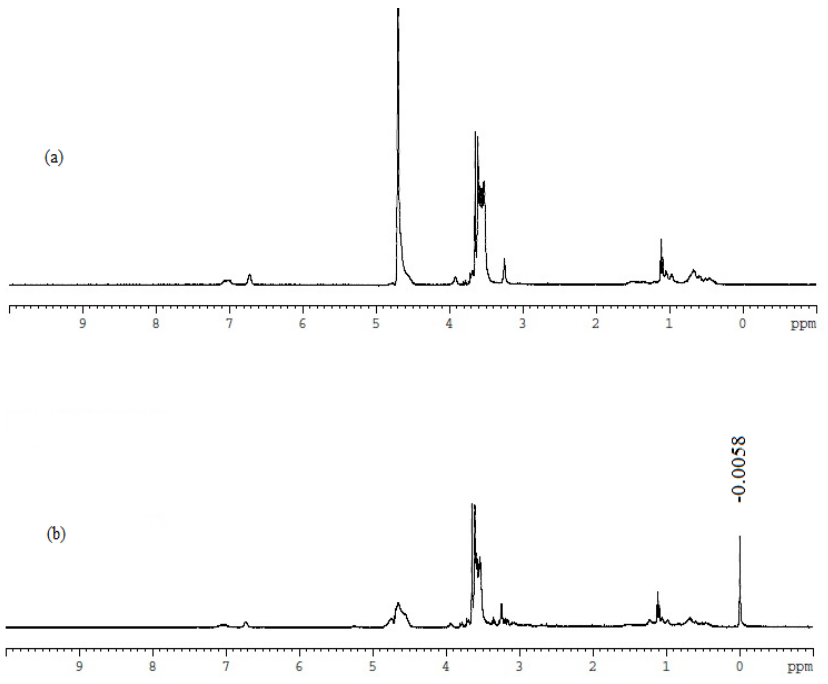

Figure 3. (a) NMR spectrum with presaturation method of Buffer solution $+\mathrm{D}_{2} \mathrm{O}$ mixture (b) NMR spectrum with presaturation method of membrane $+\mathrm{D}_{2} \mathrm{O}$ mixture
Figure $3 \mathrm{a}$ gives the ${ }^{1} \mathrm{H}-\mathrm{NMR}$ spectrum using the presaturation method of the $\mathrm{D}_{2} \mathrm{O}$ mixture with the buffer solution and Figure $3 \mathrm{~b}$ shows the same vertical scale of the ${ }^{1} \mathrm{H}-\mathrm{NMR}$ spectrum of the $\mathrm{D}_{2} \mathrm{O}$ mixture with the membrane sample. When these two spectra were compared, it was seen that the signal observed at the chemical shift value of $-0.0058 \mathrm{ppm}$ in the ${ }^{1} \mathrm{H}$-NMR spectrum of the $\mathrm{D}_{2} \mathrm{O}$ mixture with the membrane sample was observed. This signal observed at $-0.0046 \mathrm{ppm}$ in Figure $2 \mathrm{~b}$ shifted to $0.0058 \mathrm{ppm}$ in the case of presaturation.

\section{CONCLUSION}

As a result of comparison of the $400 \mathrm{MHz}{ }^{1} \mathrm{H}-$ NMR spectrum of the membrane sample with the buffer solution in which the membrane samples were homogenized, the signal to be considered was taken into account in the membrane samples. The chemical shift values and the intensity of this signal were investigated in single pulse and presaturation experiments. It is possible to measure $T_{1}$ and $T_{2}$ relaxation times at different concentrations and temperatures by adding various proteins and drugs after the normal membrane signal is located in the spectrum.

\section{ACKNOWLEDGEMENTS}

First, I thank my doctoral advisor Prof. Dr. Ali YILMAZ. This work includes a part of the doctoral dissertation that supported Dicle University Scientific Research Project (DÜBAP 08-FF-10).

\section{REFERENCES}

Abu-Baker, S., Lorigan, G.A., 2012. Solid-State NMR Spectroscopic Approaches to Investigate Dynamics, Secondary Structure and Topology of Membrane Proteins. Open Journal of Biophysics, 2(4):109-116.

Babcock, J.J., Li, M., 2014. Deorphanization the human transmembrane genome: A landscape of uncharacterized membrane proteins. Acta Pharmacologica Sinica, 35(1):11-23.

Bull, S.C., Doig, A.J., 2015. Properties of Protein Drug Target Classes. PLoS One., 10(3):1-44.

Grover, V.P.B., Tognarelli, J.M., Crossey, M.M.E., Cox, I.J., Taylor-Robinson, S.D., McPhail, M.J.W., 2015. Magnetic Resonance Imaging: Principles and Techniques: Lessons for Clinicians. Journal of Clinical and Experimental Hepatology, 5(3):246-255.

Jao, C., 2005. Basic instructions for Bruker NMR AVANCE 400 Running TOPSPIN, Guide to presaturation experiment for solvent suppression. 
DOI: 10.29132/ijpas.359756

http://nmr.bc.sinica.edu.tw/instruments/data/NMR/1 H_Presaturation.pdf

Marion, D., 2013. An introduction to biological NMR spectroscopy. Molecular \& Cellular Proteomics, 12(11):3006-3025.

Middleton, D.A., Reid, D.G., Watts, A., 2004. Combined quantitative and mechanistic study of drug-membrane interactions using a novel $2 \mathrm{H}$ NMR approach. Journal of Pharmaceutical Sciences, 93(2):507-514.

Nielsen, N., Malmendal, A., Vosegaard, T., 2004 Techniques and applications of NMR to membrane proteins. Molecular Membrane Biology, 21:129-141.

Opella, S.J., Ma, C., Marassi, F.M., 2001. Nuclear magnetic resonance of membrane-associated peptides and proteins. Methods in Enzymology, 339:285-313.

Pignatello, R., Musumeci, T., Basile, L., Carbone, C., Puglisi, G., 2011. Biomembrane models and drugbiomembrane interaction studies: Involvement in drug design and development. Journal of Pharmacy and Bioallied Sciences, 3(1):4-14.

Schnell, D.J., Hebert, D.N., 2003. Protein translocons: multifunctional mediators of protein translocation across membranes. Cell, 112(4):491-505.

Tamm, L.K., Liang, B., 2006. NMR of membrane proteins in solution. Progress in Nuclear Magnetic Resonance Spectroscopy, 48:201-210.

Thennarasu, S., Lee, D., Poon, A., Kawulka, K.E., Vederas, J.C., Ramamoorthy, A., 2005. Membrane permeabilization, orientation and antimicrobial mechanism of subtilosin A. Chemistry and Physics of Lipids, 137:38-51.

Webb, G.A., 2007. Nuclear Magnetic Resonance, 36. Cilt, Specialist Periodical Reports, Royal Society of Chemistry, Cambridge, UK.

Wüthrich, K., 1986. NMR of proteins and nucleic acids, Wiley, New York.

Xu, Y., Yushmanov, V.E., Tang, P., 2002. NMR studies of drug interaction with membranes and membraneassociated proteins. Bioscience Reports, 22:175-190.

Yilmaz, A., Zengin B., 2013. High-field NMR T2 relaxation mechanism in $\mathrm{D}_{2} \mathrm{O}$ solutions of albumin. Journal of Applied Spectroscopy, 80 (3):335-340.

Yilmaz, A, Zengin, B, Ulak, F.S., 2014. NMR proton spin-lattice relaxation mechanism in $\mathrm{D}_{2} \mathrm{O}$ solutions of albumin determined at $400 \mathrm{MHz}$. Journal of Applied Spectroscopy, 81(3):365-370. 